\title{
The Survival Rates of SMEs in Turkey and the Conceptual Framework of Factors Affecting IT
}

\author{
Erkut Akkartal ${ }^{1}$, Cihan Karamik ${ }^{2}$ \\ ${ }^{1}$ Department of International Logistics and Transportation Yeditepe University, Istanbul, Turkey \\ ${ }^{2}$ Department of Business Administration, Yeditepe University Istanbul, Turkey
}

\begin{abstract}
SMEs are vitally important enterprises as they are a source of income and employment in both developed and developing economies. However, despite their importance, only a small part of them survive for many years. Therefore, identifying the factors that enable SMEs to survive will play an important role in attracting entrepreneurs' attention and encouraging them to take steps to ensure the survival of their enterprises. In the literature, these factors are considered independently of each other. In this context, there is a gap in the literature that requires to demonstrate the relationship between these factors. This article aims to contribute to the literature by identifying factors affecting the survival of SMEs in Turkey and providing a conceptual framework that explains their relationships. In the proposed framework, managerial practices, entrepreneurial traits, market adaptation, growth management and finance management were considered as the main constructs. If this conceptual framework, which was revealed as a result of field observations and detailed literature reviews, is empirically supported by further studies, it can create an alternative perspective that will inspire SME owners in Turkey to keep their companies alive for years.
\end{abstract}

KEYWORDS: Entrepreneur Traits, Finance Management, Growth Management, Managerial Practices, Market Adoptation, SME, Survival, Turkey

\section{INTRODUCTION}

Small and medium-sized enterprises (SMEs) are the main driving forces for the development of economic and social welfare. According to OECD SME and Entrepreneurship Outlook (2019) Report, 99\% of all businesses in the OECD region are SMEs. Approximately $60 \%$ of employment, $50 \%$ to $60 \%$ of the total added value created is generated by SMEs. In this respect, they are the engine of sustainable economic growth. Very similarly, according to OECD Turkey Policy Brief Report (2016), SMEs constitute $73.5 \%$ of the total employment in Turkey and in more than $50 \%$ of the value added. Therefore, they play very critical role in reducing the unemployment, enhancing growth and international competitiveness. In this context, it has become more critical than ever for countries to better understand the conditions under which SMEs grow and survive.

Despite the dynamic and volatile economic conditions in Turkey, SMEs are struggling to provide the growth trend to continue their development and their competitiveness. Basically, SMEs in Turkey experience survival problems due to reasons such as cost disadvantages, managerial deficiencies, inadequate utilization of new technologies, difficulties in accessing finance and deficiencies in human resources. According to the Turkish Statistical Institute data, only 39,5\% of SMEs reach their $5^{\text {th }}$ year (TurkStat, Entrepreneurship and Business Demography, 2017-2019).

When the studies in the literature are examined, it is seen that, survivability problem in large businesses has been discussed in different environments for years and solutions have been sought for companies to have a longer life. The factors affecting the survival of firms are firm size and age, (Mata, J., Portugal, P., Guimaraes, P., 1995), business diversity (Cottrell, T., Nault, B.R., 2004), intensity of R\&D activities, technological innovation (Cefis, E., Marsili, O., 2006) industrial growth potential (Honjo, Y., 2000).

On the other hand, regarding the survival of SMEs there are some studies in the literature from different perspectives on the basis of developed countries. Doms, Dunne and Roberts (1995) in America, Kimura and Fujii (2003) in Japan, Harhoff, D. (1998) in Germany can be given as an example. In some studies, it has been revealed that firm size improves its sustainability. However, there is no broad study investigating the factors affecting the survival of SMEs in Turkey. On the other hand, the relationships between these factors have not been examined in existing studies. Although the value of SMEs in the country's economy and job creation is 


\section{International Journal of Current Science Research and Review}

ISSN: 2581-8341

Volume 04 Issue 10 October 2021

DOI: 10.47191/ijesrr/V4-i10-17, Impact Factor: 5.825

known, their low survival rate is an issue that needs to be investigated in depth. In this study, as an example to the developing countries, SMEs in Turkey is being addressed and the factors affecting the survival of the companies are set forth.

Thus, the purpose of this study is to reveal the factors affecting the survival of SMEs in Turkey and the relationships between these factors.

\section{LITERATURE REVIEW}

\subsection{Definition of SME}

When the literature is examined, it is understood that the definition of SME varies between countries according to its context. These companies are classified according to some qualitative and quantitative criteria. For example, the number of employees is generally used as a quantitative classification criterion in all countries. According to the OECD (2004) report, having less than a certain number of employees is the most important parameter that distinguishes these businesses from larger enterprises. businesses with under 250 employees in the European countries and Turkey in the SME counted, businesses with under 500 employees in the US and Canada are classified as SMEs (OECD, 2010). In Japan, this definition varies on a sectoral basis, and for example, those with less than 300 employees in the manufacturing sector are considered SMEs, while in the service sector this number is 100 (Chusho Meti, 2014).

According to the SME definition of the European Union, the criteria in Table 1 are based on turnover and number of employees. It is also stipulated that $25 \%$ or more of the capital of a single enterprise cannot be undertaken by an enterprise or that its capital does not belong to enterprises not defined as SMEs (OECD, 2005).

In summary, SMEs are regarded as independently operating businesses with a relatively small share of the market, managed in a personalized manner by owners or partial owners, rather than using a formal management structure (Storey, 1994).

Table 1. Categorization of SMEs in European Union

\begin{tabular}{llll}
\hline Company Size & Number of Employees & Annual Turnover & Balance Sheet Total \\
Medium-sized & $<250$ & $\leq 50 \mathrm{M} €$ & $\leq 43 \mathrm{M} €$ \\
Small & $<50$ & $\leq 10 \mathrm{M} €$ & $\leq 10 \mathrm{M} €$ \\
Micro & $<10$ & $\leq 2 \mathrm{M} €$ & $\leq 2 \mathrm{M} €$ \\
\hline
\end{tabular}

Source: Muller, Gagliardi, Caliandro, Bohn \& Klitou, (2014)

SME definition was redefined in Turkey with the "Regulation on the Amendment of the Regulation on the Definition, Qualifications and Classification of Small and Medium Sized Enterprises" published by the Council of Ministers in the Official Gazette dated June 24,2018

Accordingly, SMEs are defined as economic units or enterprises that employ less than 250 people annually and whose annual net sales income or financial balance does not exceed 125 million Turkish Liras. The basic classification is done as follows:

a) Micro-enterprise: Establishments that employ less than 10 workers per year and whose annual net sales income or balance sheet total does not exceed 3 million Turkish Liras.

b) Small business: Enterprises that employ less than 50 workers per year and whose annual net sales income or balance sheet total does not exceed 25 million Turkish Liras.

c) Medium sized enterprises: Enterprises that employ less than 250 workers per year and whose annual net sales income or balance sheet total does not exceed 125 million Turkish Liras.

This classification is described in Table 2. 


\section{International Journal of Current Science Research and Review}

ISSN: 2581-8341

Volume 04 Issue 10 October 2021

DOI: 10.47191/ijcsrr/V4-i10-17, Impact Factor: 5.825

IJCSRR@ 2021

www.ijesrr.org

Table 2. Categorization of SMEs in Turkey

\begin{tabular}{lll} 
Company Size & Number of Employees & Annual Turnover \\
Medium-sized & $<250$ & $\leq 125 \mathrm{MTL}$ \\
Small & $<50$ & $\leq 25 \mathrm{MTL}$ \\
Micro & $<10$ & $\leq 3 \mathrm{MTL}$ \\
\hline
\end{tabular}

Source: Akkartal \& Karamik, (2021)

\subsection{The importance of SMEs for countries}

Small and medium-sized enterprises account for more than $90 \%$ of all firms in emerging and advanced economies (Mbuyisa and Leonard 2017). According to OECD SME and Entrepreneurship Outlook (2019) Report, 99\% of all businesses in the OECD region are SMEs. In terms of the value they create, $40 \%$ to $60 \%$ of total GDP comes from SMEs (Igwe, Amaugo, Ogundana, Egere, and Anigbo, 2018). $40 \%$ of the total production in the world and $35 \%$ of the total exports are obtained through SMEs (Mbuyisa and Leonard 2017). When evaluated from this aspect, SMEs have a very important place in the economies of countries in terms of employment and income creation (OECD 2014; Chatterjee, Shiwaku, Gupta, Nakano, and Shaw., 2015).

According to the European Commission's 2015 report, SMEs are the backbone of the European economy with more than $99.8 \%$ of all non-financial enterprises, $58 \%$ of total value added and $66.8 \%$ of total employment.

When we look at Turkey, $55.1 \%$ of exports and $37.7 \%$ of imports were carried out by SMEs constituting $99.8 \%$ of all firms in 2014 (Kaya and Uzay 2017). According to OECD Turkey Policy Brief Report (2016), SMEs constitute 73.5\% of the total employment in Turkey and in more than $50 \%$ of the value added.

Thus, considering the contribution of SMEs to employment and income generation, their survivability becomes an important issue to be examined.

\subsection{SME survival}

Although no survival statistics specific to SMEs have been reached, the use of general survival data will give a satisfactory result. Because more than $99 \%$ of all enterprises are already in the SME class.

Figure 1 shows the 1-year, 3-year and 5-year survival rates of enterprises in the European Union countries in 2018. According to these data, approximately $80 \%$ of enterprises born in 2017 are alive by 2018, when looking at the EU average. The highest rates are in Greece, the Netherlands, Sweden and Belgium, with over $90 \%$. The lowest performance belongs to Portugal with $71.3 \%$ and Lithuania with $63.6 \%$

As can be seen in Figure 1, 3-year and 5-year survival rates are in a downward trend for all countries. It is seen that the 3-year survival rate is $59 \%$ on average among European Union countries. The countries with the highest 3-year survival rate are Switzerland, Ireland and Greece. Lithuania (38\%) and Portugal (48\%) have the lowest 3-year survival rate.

Looking at the proportion of enterprises that were born in 2013 and are still alive in 2018, it is seen that the best performance belongs to Sweden, the Netherlands and Belgium. On the other hand, in Lithuania, the 5-year survival rate is very low (28\%).

Looking at the data for Turkey, it is seen that, 1-year, 3-year and 5-year survival rates of enterprises are $80 \%, 53 \%$ and $39.5 \%$ respectively. It should be also noted that the 1-year survival rate is at the EU level, while the 3-year and 5-year survival rates are somewhat below the EU average. (EUROSTAT, 2018). 


\section{International Journal of Current Science Research and Review}

ISSN: 2581-8341

Volume 04 Issue 10 October 2021

DOI: 10.47191/ijesrr/V4-i10-17, Impact Factor: 5.825

IJCSRR@ 2021

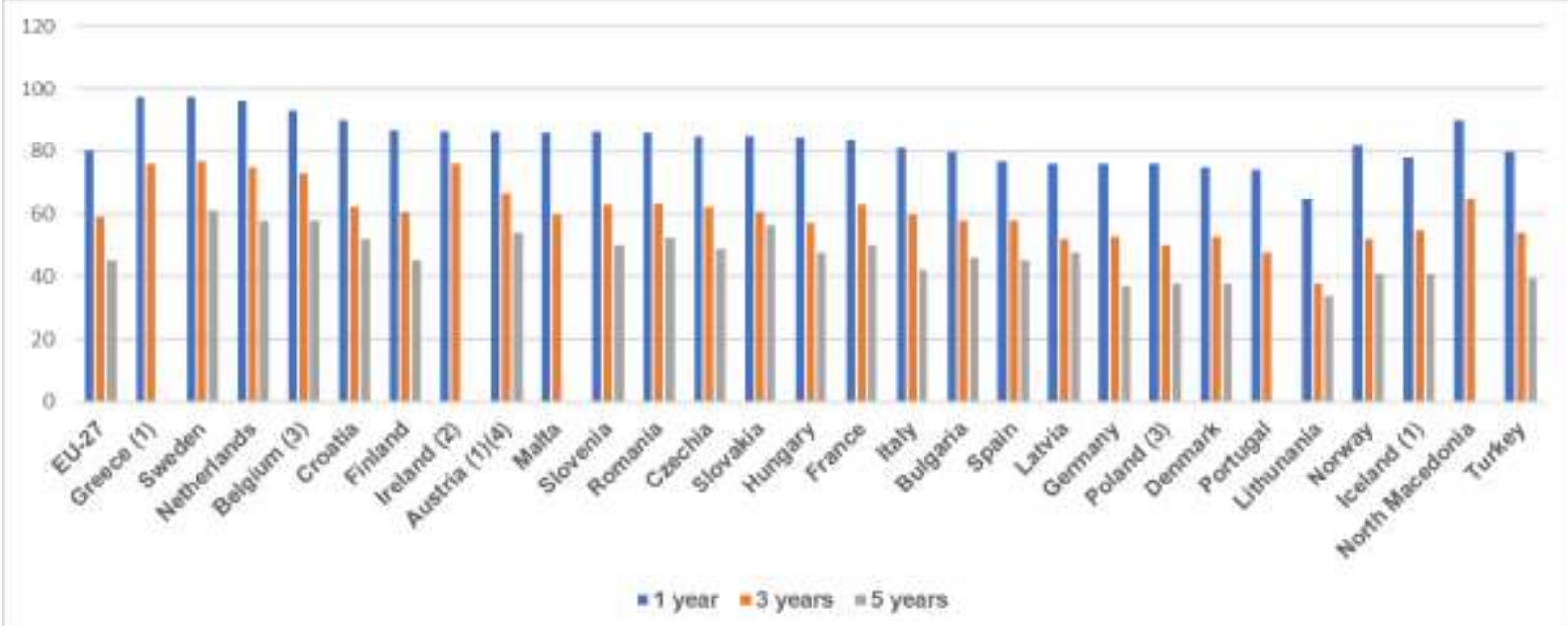

Note: Data for Estonia, Cyprus and Luxembourg is not available

(1) Provisional

(2) Estimated

(3) Break in time series

(4) Break in time series 5 years survivals

Figure 1. One, three and five-year survival rates of enterprises, business economy $2018(\%)$

Source: Eurostat (online data code: bd_9bd_sz_cl_r2)

Therefore, based on these data, it can be argued that, SMEs in Turkey experience serious survival problems due to some firm and industry specific factors and this situation is closely related to economic and social life in the country. In this context, many factors affecting the sustainability of SMEs have been studied in the literature before.

\subsection{Affecting factors of SME survival}

When the literature is examined, many factors that affect the survival success of companies in developing and developed countries are encountered. However, it may be possible to categorize them as internal factors that are mostly related to the companies' own resources and capabilities and external factors that can be associated with the environment, they live in. These factors are summarized below.

\subsection{Firm-level Factors}

\subsubsection{Age and Size}

The corporate capabilities of enterprises are formed over time. Establishing the business, making investments, developing knowhow, and achieving harmony within the organization and with the environment takes time (Carroll \& Hannan, 2000). During this period of development, enterprises have to deal with environmental challenges more than older enterprises (Freeman, Carroll \& Hannan, 1983).

Studies in the literature have found a significant correlation between the age and scale of firms and their survival rates, and it has been shown that large-scale firms can live longer than small-scale firms, while older firms can live longer than younger firms (Freeman et al., 1983, Ericson and Pakes, 1995, Geroski, 1995). The experience, management skills, production efficiency and process efficiency gained by the firms are directly proportional to the size and age of those firms. In addition, as the scale of firms grows, their access to financial resources, tax benefits and reaching more qualified human capital may increase. The effect of firm size and age on survival rate may differ by sector and this relationship is not linear (Harhoff, Stahl \& Woywode, 1998, Agarwal and Gort, 2002). Newly established enterprises can survive with low risk with the financial support they get in the organization. As these resources dwindle, the risks of survival increase and then begin to decline again because only suitable firms remain in the market (Bruderl and Schussler, 1990, Fichman and Levinthal, 1991). 


\section{International Journal of Current Science Research and Review}

ISSN: 2581-8341

Volume 04 Issue 10 October 2021

DOI: 10.47191/ijesrr/V4-i10-17, Impact Factor: 5.825

IJCSRR@ 2021

www.ijcsrr.org

\subsubsection{Managerial Practices}

SMEs are managed by owners rather than professional managers due to their scales and structures. Therefore, success or failure usually depends on the skills of the owner manager or entrepreneur, not the management processes and practices of the business (Hudson-Smith and Smith, 2007). Many SMEs are commanded and controlled by the experiences and common sense of the dominant leaders and their course is determined in this way (Ates and Bititci, 2011).

Owners who manage SMEs act more to meet daily operational problems and short-term needs of customers, rather than working towards long-term strategic goals. This means that their priority is short-term operational jobs (Jennings \& Beaver, 1997).

In these enterprises, there is a perception that being competitive can only be achieved by doing better technically, and some managerial practices will not have much benefit. In addition, introverted planning predominates in the managerial practices of these enterprises (Cagliano, Blackmon and Voss, 2001). Successful SMEs develop more outward-looking practices and constantly monitor external economic conditions, business conditions, technological requirements, and their market positions (Day and Schoemaker, 2005). In large companies, operational and managerial practices are determined by formal processes, while in SMEs these processes are less defined, more owner managers decide how to make decisions for daily operations and how to manage growth.

Managerial practices in SMEs are closely related to the entrepreneur's skills, educational background and personal characteristics. Owners who manage SMEs follow both strategic and operational jobs together, but they may neglect managerial jobs as their diversified skills may be limited (Fuller-Love, 2006).

Therefore, owner managers are not too ambitious to go beyond what they can manage everything on their own and grow their companies (Gray, 2002). Improving the organizational skills of these companies actually means improving the skills of managers (Fuller-Love, 2006). For many managers, the job they do is an extension of their ego, and the factor that determines the decisionmaking processes is not the development of their job but the suitability of their own lifestyle (Banfield, Jennings and Beaver, 1996). However, in the study conducted by Filion (1996), which examines professional managers and owners, it is claimed that this entrepreneurship will encourage business ownership, seeking more opportunities and process improvement.

According to Cagliano et al. (2001), SMEs need to develop and encourage more advanced and systematic management approaches to achieve a sustainable performance. The firm's ability to maintain its competitive advantage depends on how the management applies these systematic managerial processes while controlling and managing the company (Fuller-Love, 2006).

\subsubsection{Entrepreneur Traits}

The founders of companies also play a very important role as people who determine how organizations are structured and what their strategies will be. The leaders' personality traits will have an impact on the firm's strategic direction (Judge, Piccolo and Kosalka, 2009). This situation may be more determinant for companies of SME scale. Therefore, the characteristics of company founders and owners are a factor closely related to the survival success of companies. For example, the education level of these people has been found to be an important parameter affecting the performance of the firm.

Managerial competencies are the leading entrepreneurial traits to implement certain practices for the performance of SMEs. Managerial competencies are associated with past management experience, education level, knowledge level and whether or not they have established a business before (Hisrich \& Drnovsek, 2002).

\subsubsection{Location}

It can be argued that the choice of the first place of entry, some factors such as agglomeration economies will affect the survival of firms. However, there is not enough empirical evidence on this subject in the literature. For example, there are two separate findings on how agglomeration affects survival. While Fotopoulos and Louri (2000) stated that the survival rates of enterprises established in areas with heavy urbanization were higher than those in rural ones, Strotmann (2007) claimed the opposite and Honjo (2000) stated that industrial clustering increased the risk of death of firms.

\subsubsection{R\&D Activity}

According to the Resource-Based theory, the survival expectancy of firms largely depends on the ability to develop different skills 


\section{International Journal of Current Science Research and Review}

ISSN: 2581-8341

Volume 04 Issue 10 October 2021

DOI: 10.47191/ijcsrr/V4-i10-17, Impact Factor: 5.825

IJCSRR@ 2021

Www.ijcsrr.org

(Barney, 1991). The probability of companies investing in R\&D to develop a significant competitive advantage over their competitors is very high. These activities can be spread throughout the company and can also enable the development of new skills and competencies (Klette, 1996).

\subsubsection{Advertising}

Investments in advertising activities are also one of the factors that affect the survival rate of firms. Firms can increase their market access and contribute to their productivity through advertising. Advertising spending can be viewed as sunk costs that increase firms' perception of quality and make customers willing to buy products or services at higher prices.

Advertising activities also play a role in reducing competition, as it makes market entry difficult. This increases the survival expectancy of firms investing in advertising (Comanor and Wilson, 1967).

\subsubsection{Export Activity}

SMEs that can export have a higher chance of survival than SMEs that cannot. Although the positive impact of exporting at the firm, industry and country level is diminishing slightly, this reality does not change (Esteve, Manez and Sanchis, 2008). Other studies in the literature have revealed similar results. For example, in the study of Melitz (2003), it was stated that there is a positive relationship between export activity and firm productivity. In the study of Greenway and Kneller (2007), it was claimed that exporting companies worked more efficiently than non-exporting companies. In the study of Kimura and Kiyota (2006), it was found that the productivity of exporting firms was $15 \%$ higher than that of non-exporting firms. Dzhumashev, Mishra and Smyth (2016), on the other hand, argued that productivity and profitability were increased by exporting, and the chances of survival increased by pushing inefficient companies out of the game. SMEs are less capable than large companies, as access to foreign markets, access to information networks and entering international trade requires significant costs (Fliess, Jong Lee, Dubreuil and Agatielloet, 2006).

\subsubsection{Innovation and Technology Use}

In fact, flexible structures of SMEs can facilitate innovation in organizational structures and delivery models. However, concerns over financing and lack of the necessary skills outpace SMEs in technology use and innovation (OECD 2018). When the literature is examined, it is seen that there are studies that examine the relationship between firms' technological activities and their survival probability. For example, in the study conducted by Ericson and Pakes (1995), it was revealed that firms' technological activities and innovations determine the survival rate, growth and exit rate. In the study of Gort and Klepper (1982), it was found that newly established companies can innovate by using technology and knowledge, which will facilitate the survival of the firm. Audretsch and Mahmood (1995) found that small start-ups have higher innovation capability compared to large firms, which in turn increases their chances of survival. In addition, it was thought that technological activities could both help companies survive and prevent them (Agarwal and Prasad, 1998). Although the chance of the newly established company to live in a high-tech environment is high, there is also a high risk of damage. Because the technology used is likely to get old quickly. There is also a positive relationship between firm size and the size of the benefit to be gained from innovations. This affects the survival of firms. (Cohen and Klepper, 1996).

\subsubsection{Finance Mangement}

Access to finance is critical to the survival and growth of SMEs (Robb \& Robinson, 2014, Saridakis, Mole, \& Storey, 2008). When access to financial resources is limited, the technological and innovative activities of SMEs are limited and they cannot create a competitive advantage for growth. Even if their growth potential is high, in such a situation, they have to be content with their internal resources and this prevents them from investing. This access opportunity differs between SMEs operating in developed and developing economies. In fact, SMEs in developing economies have less access to financial resources compared to SMEs in developed countries (Hanedar, Broccardo, \& Bazzana, 2014). The OECD 2015 report says that one reason for SMEs' difficulties in accessing financial resources in developing countries is related to the tendency to operate outside the formal system to evade legislation and taxation.

On the other hand, when the financial and accounting knowledge of the owner managers managing SMEs is evaluated, it is seen that they are at a very basic level and they have problems with financial literacy (Abdel, Rowena, \& Robyn, 2010). In another study, 


\section{International Journal of Current Science Research and Review}

ISSN: 2581-8341

Volume 04 Issue 10 October 2021

DOI: 10.47191/ijesrr/V4-i10-17, Impact Factor: 5.825

it was revealed that the owner managers of SMEs have little competency on financial issues, therefore they have difficulty in making financial planning, and they do not benefit from financial statements adequately while making these plans (Alattar, Kouhy \& Innes, 2009).

\subsubsection{Human Capital}

In increasing the survival probability of companies, it is also important to have a sustainable competitive advantage by investing in technology, as well as to have extensive information resources and to turn this again into a competitive advantage. It is possible for the technology used to be imitated or purchased by others. However, it is not possible to think the same for human capital (Teece 1998). In fact, using existing technologies is highly dependent on qualified human capital Autor, Levy and Murnane (1998). Although the information is implicit and integrated into the processes of companies, it is actually held by individuals. In this context, the education level of company employees determines the ability to have the required knowledge and to access new knowledge (Grant, 1996). Therefore, human capital in SMEs is an important parameter that shows managerial competence and affects survival.

On the other hand, human capital also affects labor productivity, and labor productivity affects the survival chances of the firm. Firms with low productivity have a lower chance of survival than those with high productivity (Ericson and Pakes, 1995 \& Melitz, 2003).

\subsection{Industry-Level Factors}

\subsubsection{Industry Growth}

The growth rate of the industry in which SMEs operate is also a factor affecting the survival probability. SMEs operating in growing and demanding sectors are expected to have a higher chance of survival. Due to the high demand in these sectors, competition is not very fierce. Some studies in the literature revealed a positive relationship between industry growth and survival rates (Mata and Portugal, 1994).

In addition, the ability of the SME to adapt to the industry in which it operates affects its survival. According to Pavitt's (1984) classification, there are four different industry groups and these are classified according to the characteristics of the operating companies such as competitiveness, production structure and innovation skills. These four industries can be listed as follows. Traditional industries, industries of economies of scale, specialized industries and R\&D intensive industries

\subsubsection{Competition}

As an industry specific parameter, intensity of competition is an important part of the characteristics that determine the survival of companies. The effect-reaction pair is an important concept from a theoretical point of view. Because competitive clashes occur in which companies competing at this level determine their strategies, acquire and retain new customers, protect their brand perception and reputation and show their endurance (Chen, and Hambrick, 1995).

There will always be a risk that the reactions of existing firms will suppress post-entry prices or restrict the sales of new entrants. With the acquisition of additional resources and capacity, new entrants can threaten the market profitability and market shares of existing companies. Existing companies will oppose this by means of aggressive advertising policy, low price, entering the market of new entrants. In other words, the reaction of existing companies is to suppress the shares (profit, market, etc.) that new entrants can obtain. Therefore, this reaction will mean riskier, sunk cost investments for new entrants. Severe reaction by existing firms will either drive new entrants out of the industry or new firms will have to endure poor performance (Sharma and Kesner, 1996).

\subsubsection{Macroeconomic Conditions}

SMEs are heavily dependent on the local supply chain and local resources in the region where they operate. In addition, the consumer base of these businesses may be relatively small, leaving them more vulnerable to macroeconomic or industry-specific problems (Neagu 2016).

Firms interact with their environment and face opportunities and obstacles arising from this. Studies in the literature have taken into account the relationship between firm survival and macroeconomic conditions, to a lesser extent, when examining the post-entry performance of firms. Generally, short periods that do not even cover a complete business cycle are examined (Boeri \& Bellmann, 1995). However, it does not mean that the probability of survival of these companies and the environmental relationship is ignored. 


\section{International Journal of Current Science Research and Review}

ISSN: 2581-8341

Volume 04 Issue 10 October 2021

DOI: 10.47191/ijesrr/V4-i10-17, Impact Factor: 5.825

Highfield and Smiley (1987) found that low macroeconomic growth rates, low interest rates and high unemployment increased new entry rates.

\section{THE PROPOSED CONCEPTUAL FRAMEWORK}

This conceptual framework is developed based on an extensive literature review to identify the determinants of the survival of SMEs in Turkey as an example of the developing countries. The studies in the literature categorize the factors affecting the survival of firms in general but more specifically of SMEs as internal factors at firm level and external factors at industry level and identifies a number of sub-determinants under each. Internal factors are mostly related to the companies' own resources and capabilities and external factors can be associated with the environment, they live in. Despite these factors have been examined in detail in the literature review part, the proposed conceptual framework, group these determinants from a different perspective and aims to unite in a single framework. It is perhaps one of the few studies in Turkey done in this sense. The proposed conceptual framework is shown in Figure 3.

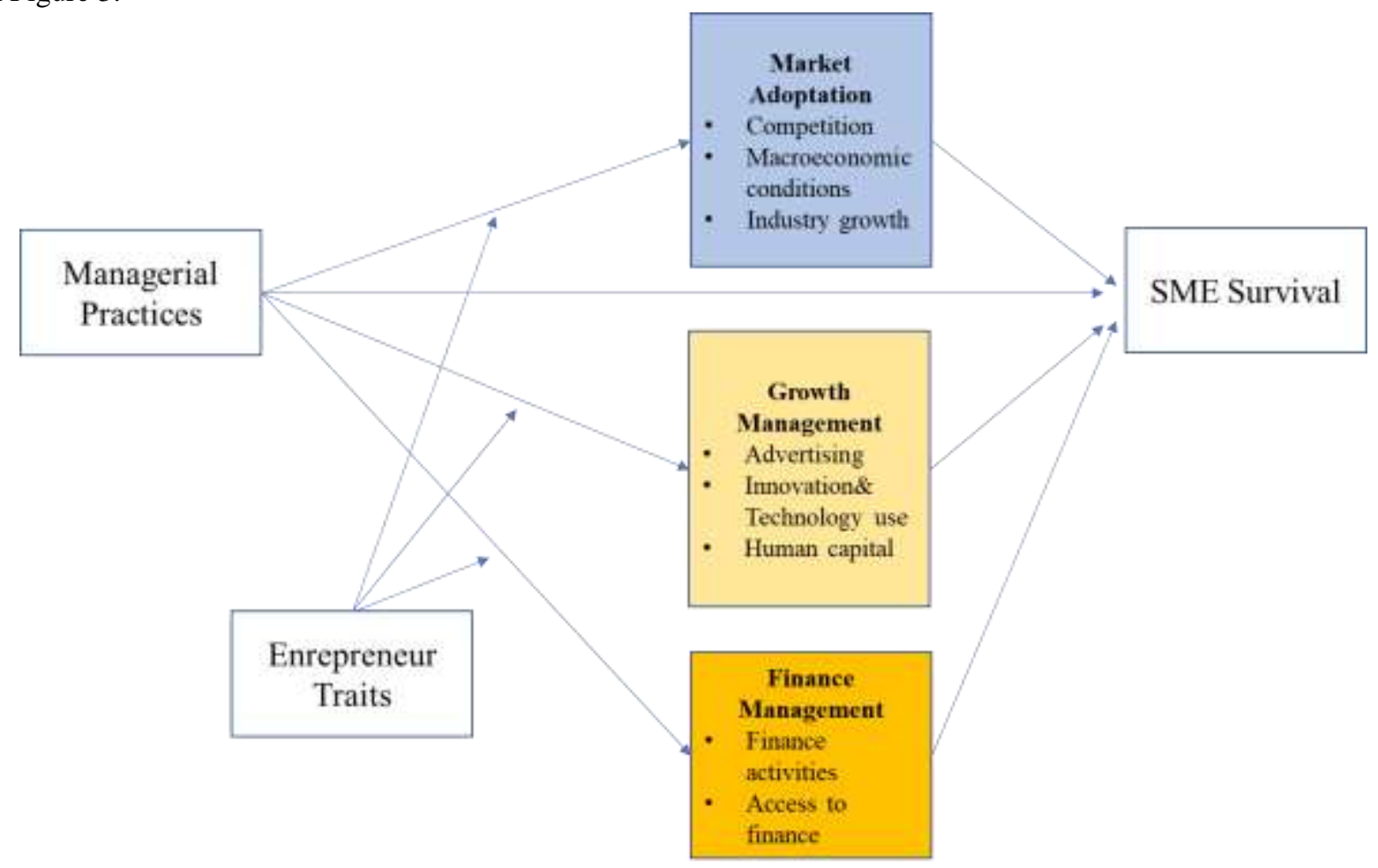

Figure 2. The proposed conceptual framework

\subsection{Managerial practices and SME Survival}

SMEs are generally managed by entrepreneurs and founders (Burger-Helmchen, 2008), and this plays a key role in determining the firm's future and survival prospects (Wincent and Westerberg, 2005). Managerial practices are closely related to the survival of the company, but it becomes even more important when it comes to SMEs. Because, SME-scale managerial practices depend on the skills, experiences, visions and priorities of the owners, not systematic processes. Owner managers determine the survival chance of their companies with the managerial practices they do or do not do.

\subsection{Managerial practices, market adoptation and SME survival}

Managerial practices also affect SME's adaptation to the market. Market adaptation may have several dimensions, but in this study, we only dealt with competition, macroeconomic conditions and the growth rate of the industry in which the firm operates.

The impact related to competition may occur due to reasons such as losing the customer and the market due to managerial practices, not following the difficulties experienced by the customer, not following the skills of the competitors and the products or services 


\section{International Journal of Current Science Research and Review}

ISSN: 2581-8341

Volume 04 Issue 10 October 2021

DOI: 10.47191/ijesrr/V4-i10-17, Impact Factor: 5.825

IJCSRR@ 2021

Www.ijesrr.org

they have developed for their customers, not being accepted even if they are followed. Losing market share is often perceived by the SME owner as "an external development that cannot be intervened". However, an SME has the flexibility to closely monitor the progress of its customers and its competitors, to reduce and increase their own investments, and to take the right position in the market.

A similar situation is also valid for the characteristics of the macroeconomic conditions in which SMEs operate. The tightness and high interest in monetary policies can increase the borrowing costs of companies significantly and this situation may deteriorate the financial situation of companies (Barton and Gordon, 1988). Fluctuations in inflation can threaten the survival of firms by complicating cash flow management (Wadhwani, 1986). In such conditions, financial and managerial practices to be implemented with the help of managerial competencies will be a significant determinant of the survival of SMEs.

On the other hand, developing managerial practices according to the type of the industry the SME is in will increase compliance and success. For example, an SME operating in an R\&D-intensive industry with emphasis on innovative activities will strengthen market adaptation.

A market adaptation achieved in all these ways will make the SME more resilient to the challenging market and industrial conditions and allow it to survive. Therefore, we anticipate that market adaptation will mediate the relationship between managerial practices and SME survival.

\subsection{Managerial practices, growth management and SME survival}

Multiple dimensions have been brought up in the literature while managing growth. However, in this study, we will only deal with marketing and advertising activities, innovation and technology use and human capital.

Since each dimension is described in detail in the literature review section, it is not discussed again here. However, it should be emphasized that some of the SMEs that fail to survive go bankrupt because they are unable to manage growth and neglect the people and capital they need as the business grows. Managing growth is a challenging process for SMEs and requires timely and strong managerial practices. A small business may not be able to find good, right human resources on its growth path, whether it realizes or wants it or searches a lot. Even if he finds it, he may not be able to convince with its scale. The technology and innovation investment required for growth or the increasing working capital need may not be able to find the loan, but it may not be able to obtain it at reasonable costs.

At this point, the flexibility and vision of the entrepreneur are important. They may not be able to convince the person they find and wants to take with him with a salary, but if one is brave about giving shares and giving dividends, conditions can be established that many good professionals will accept.

Likewise, the funding source may not be available or on unsuitable conditions. If it is open to the alternatives of getting a shareholder or merging with a small business like itself, significant improvement can be achieved in capital supply.

Therefore, we think that managerial practices affect growth management, and growth management affects the survival of SMEs. Growth management also mediates this relationship.

\subsection{Managerial practices, finance management and SME survival}

Finance management is about the disciplined skillful management of pricing and cash flow on the one hand, and the ability to access the financial resources needed for growth on the other. The bad managerial practices of this factor start with the price and payment term concessions that the small business makes for the sake of gaining a place in the market, gaining customers, and most companies will hardly survive if they are not recognized and corrected in time. Every business of any scale has to make a profit. If price concessions are a constant policy, it becomes impossible for the firm to survive.

The payment term works in the same way. The large enterprise that purchases the product asks the SME to continually extend the payment term. If SMEs with weak bargaining power cannot stand against this with some managerial practices, they have to strengthen their capital. Even if they can find it, they have to bear the loan cost directly. The buyer who wants to extend the term does not want to bear the loan interest, which is the cost of this term, and wants to transfer this burden to his supplier. This again affects the survival of the company. 


\section{International Journal of Current Science Research and Review}

ISSN: 2581-8341

Volume 04 Issue 10 October 2021

DOI: 10.47191/ijcsrr/V4-i10-17, Impact Factor: 5.825

IJCSRR@ 2021

Www.ijesrr.org

The increase in raw material costs creates two similar negative consequences. Both the amount of stock to be financed increases and the SME cannot impose these price increases on the buyers immediately. The loss and credit burden that occurs in the time until it is accepted can be fatal for SMEs. Therefore, it is a big risk for SMEs to sell low value-added products. In trade where the share of raw materials in the product is large, SMEs should make agreements with their buyers to exclude the raw material or to keep the account separate. It must persuade the buyer to contribute to the financing of the stock and to reflect the raw material price increases in the price of the product immediately.

On the other hand, the issue of access to financial resources is particularly compelling case for SMEs in developing countries such as Turkey. This is clearly seen when looking at loan usage rates. The low rate of loan utilization is also closely related to managerial practices. Many SME owners prefer to operate informally in order not to be subject to legislation and not to be visible in taxation and other financial transactions (OECD, 2006). Businesses that do not use loans, although they need it, can go to death step by step.

\subsection{Managerial practices, entrepreneurial traits and market adoptation / growth management / finance management}

As mentioned above, it is predicted that there is an important and significant relationship between the survival of SMEs and managerial practices. On the other hand, the company owners, that is, the owner managers, are mostly responsible for these managerial practices of SMEs. In other words, individual characteristics are at the forefront instead of systematic processes. In this context, it is predicted that personality traits will moderate the proposed relationship between managerial practices and market adaptation / growth management / finance management, that is, the relationship between managerial practices and market adaptation / growth management / finance management will become stronger as the characteristics of the owner manager such as education level, vision, past experiences and managerial skills become stronger.

\section{CONCLUSION}

SMEs are critical players for Turkey as well as for every country. Increasing the survival rate of SMEs is very important in terms of generating income for the country's economy and growing employment. Being aware of the factors affecting survival and the relationships between them and taking necessary remedial measures accordingly will support survival. The conceptual framework proposed in this article links SME survival to managerial practices. Because firms of this size are mostly managed by company owners or entrepreneurs, and their decisions or actions determine the fate of the firm. However, some constructs regarding the SME's owner's ability to adapt to the market in which it operates, how they manage growth and how successful they are in finance management mediate this effect. The personal characteristics of the owner managers or entrepreneurs also have a role that moderates the relationship between managerial practices and mediating constructs.

\section{IMPLICATIONS FOR FUTURE STUDIES}

This article provides a conceptual framework that can contribute to improving the survival performance of SMEs by presenting a new perspective on factors affecting the survival of SMEs. Previous studies in the literature grouped the factors affecting the survival of SMEs into internal and external factors, but they did not display a holistic and simplistic understanding. The conceptual framework presented here aims to make all these factors more explanatory by grouping them from another perspective and associating them with each other, rather than mechanically separating them into internal and external. For this purpose, several mediating and moderating effects were predicted. There are, of course, potential areas for development of this conceptual framework to further elaborate the role of the constructs used. First, the hypotheses to be developed at operational level should take into account that the relationships between the constructs proposed in this conceptual framework may not be linear. Secondly, some moderation factors such as age, scale, location of activity can be added to this framework. Third, certain research methods should be developed to test the constructs specified in this framework. Using these methods, in the first stage, performing empirical tests in SMEs across the country, in the second stage, performing experimental tests in the country but in different sub-cultures and industries, and in the third stage, testing in several similar developing countries will reveal the replicability and generalizability of this study.

\section{REFERENCES}

1. Agarwal, R., \& Gort, M. (2002). Firm and Product Life Cycles and Firm Survival. American Economic Review, 92(2), 184-190. https://doi.org/10.1257/000282802320189221 


\section{International Journal of Current Science Research and Review}

ISSN: 2581-8341

Volume 04 Issue 10 October 2021

DOI: 10.47191/ijesrr/V4-i10-17, Impact Factor: 5.825

IJCSRR@ 2021

WwW.ijcsrr.org

2. Agarwal, R., \& Prasad, J. (1998). A Conceptual and Operational Definition of Personal Innovativeness in the Domain of Information Technology. Information Systems Research, 9(2), 204-215. https://doi.org/10.1287/isre.9.2.204

3. Alattar, J. M., Kouhy, R., \& Innes, J. (2009). Management accounting information in micro enterprises in Gaza. Journal of Accounting \& Organizational Change, 5(1), 81-107. https://doi.org/10.1108/18325910910932223

4. Ates, A., \& Bititci, U. (2011). Change process: A key enabler for building resilient SMEs. International Journal of Production Research, 49(18), 5601-5618. https://doi.org/10.1080/00207543.2011.563825

5. Audretsch, D. B., \& Mahmood, T. (1995). New firm survival: new results using a hazard function. Review of Economics \& Statistics, 77(1), 97-103. https://doi.org/10.2307/2109995

6. Autor, D. H., Levy, F., \& Murnane, R. J. (2003). The skill content of recent technological change: An empirical exploration. Quarterly Journal of Economics, 118(4), 1279-1333. https://doi.org/10.1162/003355303322552801

7. Banfield, P., Jennings, P. L., \& Beaver, G. (1996). Competence-based training for small firms - An expensive failure? Long Range Planning, 29(1), 94-102. https://doi.org/10.1016/0024-6301(95)00070-4

8. Barney, J. (1991). Firm Resources and Sustained Competitive Advantage. Journal of Management, 17(1), 99-120. https://doi.org/10.1177/014920639101700108

9. Barton, S. L., \& Gordon, P. J. (1988). Corporate strategy and capital structure. Strategic Management Journal, 9(6), 623632. https://doi.org/10.1002/smj.4250090608

10. Boeri, T., \& Bellmann, L. (1995). Post-entry behaviour and the cycle: Evidence from Germany. International Journal of Industrial Organization, 13(4), 483-500. https://doi.org/10.1016/0167-7187(95)00501-3

11. Bruderl, J., \& Schussler, R. (1990). Organizational Mortality: The Liabilities of Newness and Adolescence. Administrative Science Quarterly, 35(3), 530-547. https://doi.org/10.2307/2393316

12. Cagliano, R., Blackmon, K., \& Voss, C. (2001). Small firms under MICROSCOPE: International differences in production/operations management practices and performance. Integrated Manufacturing Systems, 12(6-7), 469-482. https://doi.org/10.1108/eum0000000006229

13. Carroll, G. R., \& Hannan, M. T. (2000). Why corporate demography matters: Policy implications of organizational diversity. California Management Review, 3, 148-163. https://doi.org/10.2307/41166046

14. Cefis, E., \& Marsili, O. (2006). Survivor: The role of innovation in firms' survival. Research Policy, 35(5), 626-641. https://doi.org/10.1016/j.respol.2006.02.006

15. Cefis, E., \& Marsili, O. (2005). A matter of life and death: Innovation and firm survival. Industrial and Corporate Change, 14(6), 1-26. https://doi.org/10.1093/icc/dth081

16. Chatterjee, R., Shiwaku, K., Das Gupta, R., Nakano, G., \& Shaw, R. (2015). Bangkok to Sendai and Beyond: Implications for Disaster Risk Reduction in Asia. International Journal of Disaster Risk Science, 6(2), 177-188. https://doi.org/10.1007/s13753-015-0055-4

17. Chen, M.-J., \& Hambrick, D. C. (1995). Speed, Stealth, and Selective Attack: How Small Firms Differ from Large Firms in Competitive Behavior. Academy of Management Journal, 38(2), 453-482. https://doi.org/10.5465/256688

18. Cohen, W. M., \& Klepper, S. (1996). Firm size and the nature of innovation within industries: The case of process and product R\&D. Review of Economics and Statistics, 78(2), 232-243. https://doi.org/10.2307/2109925

19. Comanor, W. S., \& Wilson, T. A. (1967). Advertising Market Structure and Performance. The Review of Economics and Statistics, 49(4), 423-440. https://doi.org/10.2307/1928327

20. Council of Ministers in the Official Gazette dated June 24, 2018.

21. Cottrell, T., \& Nault, B. R. (2004). Product variety and firm survival in the microcomputer software industry. Strategic Management Journal, 25(10), 1005-1025. https://doi.org/10.1002/smj.408

22. Day, G. S., \& Schoemaker, P. J. H. (2005). Scanning the periphery. In Harvard Business Review (Vol. 83, Issue 11, pp. 115).

23. Doms, M., Dunne, T., \& Roberts, M. J. (1995). The role of technology use in the survival and growth of manufacturing plants. International Journal of Industrial Organization, 13(4), 523-542. https://doi.org/10.1016/0167-7187(95)00503-X

24. Dzhumashev, R., Mishra, V., \& Smyth, R. (2016). Exporting, R\&D investment and firm survival in the Indian IT sector. Journal of Asian Economics, 42, 1-19. https://doi.org/10.1016/j.asieco.2015.10.002 


\section{International Journal of Current Science Research and Review}

ISSN: 2581-8341

Volume 04 Issue 10 October 2021

DOI: 10.47191/ijcsrr/V4-i10-17, Impact Factor: 5.825

IJCSRR@ 2021

Www.ijcsrr.org

25. Esteve-Pérez, S., Máñez-Castillejo, J. A., \& Sanchis-Llopis, J. A. (2008). Does a "survival-by-exporting" effect for SMEs exist? Empirica, 35(1), 81-104. https://doi.org/10.1007/s10663-007-9052-1

26. EUROSTAT. (2018). One, three and five-year survival rates of enterprises, business economy

27. Fichman, M., \& Levinthal, D. A. (1991). HONEYMOONS AND THE LIABILITY OF ADOLESCENCE: A NEW PERSPECTIVE ON DURATION DEPENDENCE IN SOCIAL AND ORGANIZATIONAL RELATIONSHIPS. Academy of Management Review, 16(2), 442-468. https://doi.org/10.5465/amr.1991.4278962

28. Filion, L. J. (1996). Differences in managerial systems of owner-managers - Small-business entrepreneurs and smallbusiness operators. CANADIAN JOURNAL OF ADMINISTRATIVE SCIENCES-REVUE CANADIENNE DES SCIENCES DE L ADMINISTRATION, 13(4), 35-55.

29. Fliess, B., Lee, H., Dubreuil, O. L., \& Agatiello, O. (2007). Csr and Trade: Informing Consumers about Social and Environmental Conditions of Globalised Production. OECD Papers, 7(1).

30. Fotopoulos, G., \& Louri, H. (2000). Location and Survival of New Entry. Small Business Economics, 14(4), 311-321. https://doi.org/10.1023/A:1008180522759

31. Freeman, J., Carroll, G. R., \& Hannan, M. T. (1983). The Liability of Newness: Age Dependence in Organizational Death Rates. American Sociological Review, 48(5), 692-710. https://doi.org/10.2307/2094928

32. Fuller-Love, N. (2006). Management development in small firms. In International Journal of Management Reviews (Vol. 8, Issue 3, pp. 175-190). https://doi.org/10.1111/j.1468-2370.2006.00125.x

33. Gagliardi, D., Caliandro, C., Bohn, N. U., Vidal, D., Probst, L., \& Schiersch, A. (2014). Annual Report on European SMEs 2013 / 2014 - A Partial and Fragile Recovery Final Report. SME Performance Review 2013 / 2014.

34. Geroski, P. A. (1995). What do we know about entry? International Journal of Industrial Organization, 13(4), 421-440. https://doi.org/10.1016/0167-7187(95)00498-X

35. Gort, M., \& Klepper, S. (1982). Time Paths in the Diffusion of Product Innovations. The Economic Journal, 92(367), 630653. https://doi.org/10.2307/2232554

36. Grant, R. M. (1996). Toward a knowledge-based theory of the firm. Strategic Management Journal, 17(SUPPL. WINTER), 109-122. https://doi.org/10.1002/smj.4250171110

37. Gray, C. (2002). Entrepreneurship, resistance to change and growth in small firms. Journal of Small Business and Enterprise Development, 9(1), 61-72. https://doi.org/10.1108/14626000210419491

38. Greenaway, D., \& Kneller, R. (2007). Firm heterogeneity, exporting and foreign direct investment. In Economic Journal (Vol. 117, Issue 517, pp. 134-161). https://doi.org/10.1111/j.1468-0297.2007.02018.x

39. Halabi, A. K., Dyt, R., \& Barrett, R. (2010). Understanding financial information used to assess small firm performance: An Australian qualitative study. Qualitative Research in Accounting \& Management, 7(2), 163-179. https://doi.org/10.1108/11766091011050840

40. Harhoff, D., Stahl, K., \& Woywode, M. (1998). Legal form, growth and exit of west German firms - Empirical results for manufacturing, construction, trade and service industries. Journal of Industrial Economics, 46(4), 453-488. https://doi.org/10.1111/1467-6451.00083

41. Highfield, R., \& Smiley, R. (1987). New business starts and economic activity. An empirical investigation. International Journal of Industrial Organization, 5(1), 51-66. https://doi.org/10.1016/0167-7187(87)90006-3

42. Hisrich, R. D., \& Drnovsek, M. (2002). Entrepreneurship and small business research - a European perspective. In Journal of Small Business and Enterprise Development (Vol. 9, Issue 2, pp. 172-222). https://doi.org/10.1108/14626000210427348

43. Honjo, Y. (2000). Business failure of new firms: An empirical analysis using a multiplicative hazards model. International Journal of Industrial Organization, 18(4), 557-574. https://doi.org/10.1016/S0167-7187(98)00035-6

44. Hudson Smith, M., \& Smith, D. (2007). Implementing strategically aligned performance measurement in small firms. International Journal of Production Economics, 106(2), 393-408. https://doi.org/10.1016/j.ijpe.2006.07.011

45. Igwe, P. A., Amaugo, A. N., Ogundana, O. M., Egere, O. M., \& Anigbo, J. A. (2018). FACTORS AFFECTING THE INVESTMENT CLIMATE, SMES PRODUCTIVITY AND ENTREPRENEURSHIP IN NIGERIA. European Journal of Sustainable Development, 7(1), 182-200. https://doi.org/10.14207/ejsd.2018.v7n1p182 


\section{International Journal of Current Science Research and Review}

ISSN: 2581-8341

Volume 04 Issue 10 October 2021

DOI: 10.47191/ijesrr/V4-i10-17, Impact Factor: 5.825

IJCSRR@ 2021

WwW.ijcsrr.org

46. Jennings, P., \& Beaver, G. (1997). The Performance and Competitive Advantage of Small Firms: A Management Perspective. International Small Business Journal, 15(2), 63-75. https://doi.org/10.1177/0266242697152004

47. Judge, T. A., Piccolo, R. F., \& Kosalka, T. (2009). The bright and dark sides of leader traits: A review and theoretical extension of the leader trait paradigm. Leadership Quarterly, 20(6), 855-875. https://doi.org/10.1016/j.leaqua.2009.09.004

48. KAYA, H. P., \& UZAY, Ş. (2017). The Risks That Will Threaten Going Concern and Control Recommendations: Case Study on SMEs. İşletmelerin Sürekliliğini Tehlikeye Düşürecek Riskler ve Kontrol Önerileri: KOBİlerde Bir Uygulama., July, 46-64.

49. Kimura, F., \& Fujii, T. (2003). Globalizing activities and the rate of survival: Panel data analysis on Japanese firms. Journal of the Japanese and International Economies, 17(4), 538-560. https://doi.org/10.1016/j.jjie.2003.08.003

50. Kimura, F., \& Kiyota, K. (2006). Exports, FDI, and productivity: Dynamic evidence from Japanese firms. Review of World Economics, 142(4), 695-719. https://doi.org/10.1007/s10290-006-0089-1

51. Klette, T. J. (1996). R\&D, Scope Economies, and Plant Performance. The RAND Journal of Economics, $27(3), 502$. https://doi.org/10.2307/2555841

52. Mata, J., \& Portugal, P. (1994). Life Duration of New Firms. The Journal of Industrial Economics, 42(3), $227-245$. https://doi.org/10.2307/2950567

53. Mata, J., Portugal, P., \& Guimarães, P. (1995). The survival of new plants: Start-up conditions and post-entry evolution. International Journal of Industrial Organization, 13(4), 459-482. https://doi.org/10.1016/0167-7187(95)00500-5

54. Mbuyisa, B., \& Leonard, A. (2017). The Role of ICT Use in SMEs Towards Poverty Reduction: A Systematic Literature Review. In Journal of International Development (Vol. 29, Issue 2, pp. 159-197). https://doi.org/10.1002/jid.3258

55. Melitz, M. J. (2003). The impact of trade on intra-industry reallocations and aggregate industry productivity. Econometrica, 71(6), 1695-1725. https://doi.org/10.1111/1468-0262.00467

56. Neagu, 2016. The importance and role of small and medium-sized businesses. Theoretical and Applied Economics Volume XXIII (2016), No. 3(608), Autumn, p. 331-338.

57. OECD. (2016). The importance and role of small and medium-sized businesses. Theoretical and Applied Economics, XXIII (3).

58. OECD. (2015). Financing SMEs and entrepreneurs 2015 - An OECD Scoreboard. OECD Publishing.

59. OECD. (2018). Strengthening SMEs and entrepreneurship for productivity and inclusive growth. SME Ministerial Conference, Key Issues Paper, February.

60. OECD. (2005). OECD factbook, 2005: economic, environmental and social statistics. Choice Reviews Online, 43(02). https://doi.org/10.5860/choice.43-0688

61. OECD. (2004). Promoting Entrepreneurship and Innovative SMEs in a Global Economy: Towards a More Responsible and Inclusive Globalisation. Financing Innovative SMEs in a Global Economy. 2nd OECD Conference of Ministers Responsible for Small and Medium-Sized Enterprises (SMEs) Istanbul, Turkey 3-5 June 2004, June.

62. OECD. (2019). OECD SME and Entrepreneurship Outlook 2019 Policy Highlights. OECD Publishing.

63. OECD. (2016). Turkey Policy Brief Report. OECD Better Policies Series

64. Pakes, A. (1995). Markov-perfect industry dynamics: A framework for empirical work. Review of Economic Studies, 62(1), 53-82. https://doi.org/10.2307/2297841

65. Pavitt, K. (1984). Sectoral patterns of technical change: Towards a taxonomy and a theory. Research Policy, 13(6), 343373. https://doi.org/10.1016/0048-7333(84)90018-0

66. Robb, A. M., \& Robinson, D. T. (2014). The capital structure decisions of new firms. Review of Financial Studies, 27(1). https://doi.org/10.1093/rfs/hhs072

67. Saridakis, G., Mole, K., \& Storey, D. J. (2008). New small firm survival in England. Empirica, 35(1), 25-39. https://doi.org/10.1007/s10663-007-9049-9

68. Sharma, A., \& Kesner, I. F. (1996). Diversifying entry: Some ex ante explanations for postentry survival and growth. Academy of Management Journal, 39(3). https://doi.org/10.2307/256658

69. Storey, D. J. (1994). (1994). “Understanding the Small Business Sector”, Routledge, London. In Routledge, London (Vol. 7). 


\section{International Journal of Current Science Research and Review}

ISSN: 2581-8341

Volume 04 Issue 10 October 2021

DOI: 10.47191/ijesrr/V4-i10-17, Impact Factor: 5.825

IJCSRR@ 2021

Www.ijcsrr.org

70. Strotmann, H. (2007). Entrepreneurial survival. Small Business Economics, 28(1), 87-104. https://doi.org/10.1007/s11187005-8859-z

71. Teece, D. J. (1998). Capturing Value from Knowledge Assets. California Management Review, 40, 55-79.

72. Wadhwani, S. B. (1986). Inflation, Bankruptcy, Default Premia and the Stock Market. The Economic Journal, 96(381), 120-138. https://doi.org/10.2307/2233429

73. TurkStat, Entrepreneurship and Business Demography, 2017-2019

74. Yaldiz Hanedar, E., Broccardo, E., \& Bazzana, F. (2014). Collateral requirements of SMEs: The evidence from lessdeveloped countries. Journal of Banking and Finance, 38(1), 106-121. https://doi.org/10.1016/j.jbankfin.2013.09.019

Cite this Article: Erkut Akkartal, Cihan Karamik (2021). The Survival Rates of SMEs in Turkey and the Conceptual Framework of Factors Affecting IT. International Journal of Current Science Research and Review, 4(10), 1348-1361 